\title{
Gyermekek a reneszánszban
}

\author{
Aggné Pirka Veronika*
}

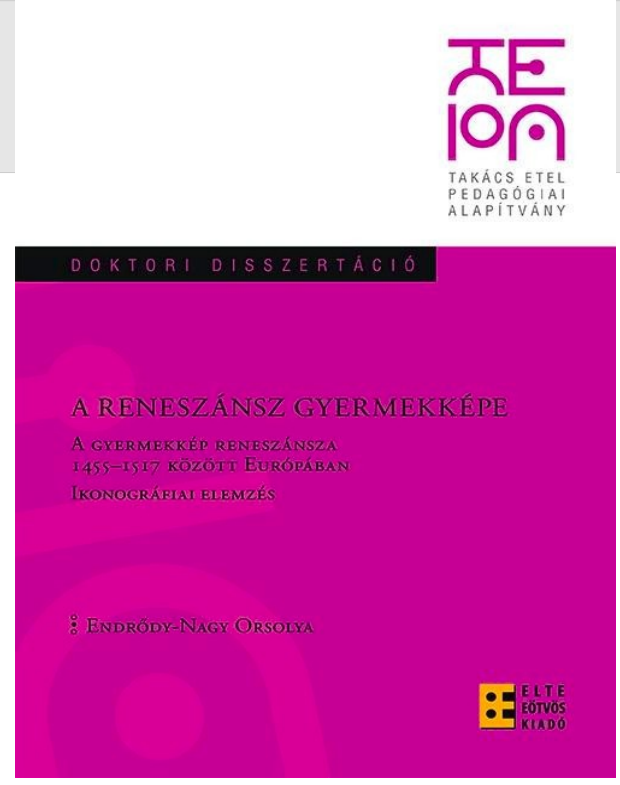

Endrödy-Nagy Orsolya (2015): A reneszánsz gyermekképe - a gyermekkép reneszánsza 1455-1517 között Európában - ikonográfiai elemzés, Takács Etel Pedagógiai Alapítvány. Budapest.

A reneszánsz gyermekképe - a gyermekkép reneszánsza 1455-1517 között Európában - ikonográfiai elemzés című munka a szerző doktori disszertációjának könyvben megjelent változata. A disszertáció előzményeként a kutatott téma egy részlete már 2013-ban megjelent a Gyermeknevelés folyóiratban (Endrödy-Nagy, 2013). A könyvben a szerző problématörténeti felvetésből kiindulva a vizsgált időszak művelődés- és művészettörténeti jelentőségét is bemutatja. EndrődyNagy a téma feldolgozása során figyelt arra, hogy az interdiszciplináris kereteket is megadja a gyermekkor, mint konstrukció értelmezéséhez. A jól tagolt könyvben ezután következnek a szerző külföldi (járt Lyonban, Bolognában) tanulmányi útjai és hazai kutatómunkája során gyűjtött elsődleges források feldolgozása, a "gyermekkép reneszánszának" bemutatása.

A könyv címe $A$ reneszánsz gyermekképe - a gyermekkép reneszánsza találó, már első olvasatra olybá tűnik, hogy egy olyan világ tárul elénk, amely új nézőpontokkal szolgál nekünk, mintegy az újjászületést szimbolizálva. A szerző már a címben megadja nemes egyszerűséggel a kutatási módszerét is: ikonográfiai elemzés. EndrődyNagy Orsolya az elsők között volt a hazai neveléstörténeti kutatók körében, aki erre a kutatási módszerre építette fel az egész munkáját. Hiszen mint ő is jelzi „kis számban születtek eddig hazánkban olyan ikonográfiai leírások, melyek a kép neveléstörténeti kutatásban betöltött szerepét korszakokra bontva, tematikusan és adatbázisszerűen tartalmazzák" (Endrôdy-Nagy, 2015. 5.). A szerző ezt a hiátust szándékozta pótolni. Kutatási módszerét tekintve több mint ikonográfiai elemzés, hiszen az ikonográfia mellett felhasználja a vizuális szociológia és a vizuális antropológia eszköztárát is. Elemzési metódusát alapvetően három irányzat alapján dolgozza ki. Felhasználja a Panofsky-féle (1984) metódust - preikonográfia, ikonográgia, ikonológia - Mietznerés Pilarczyk (2005); Bouteaud-féle (1989) kódrendszert és Collier (2010) sorozatelemzés jellemzőit, körülbelül 100 forrást felhasználva az elemzéshez. Részletesen mutatja be a szerző az ikonográfiai elemzéshez használt metódusokat a mű ötödik fejezetében.

Kutatásában 1440-től 1520-ig vizsgálja a gyermekkortörténetet. A külföldi gyermekkortörténészek többsége (például, Pollock, Cunningham) a 16. századtól vizsgálta a gyermekkor jellemzőit, míg például Shahar a 12. századtól a 15. század második negyedéig. A szerző olyan időtartamot választ, amelyet eddig még kevésbé kutattak a gyermekkortörténettel foglalkozó kutatók, így új információkkal szolgálva a tudomány számára. Neveléstudományi, művészettörténeti és művészetelméleti megközelítést alkalmaz. Körüljárja az adott korszak jellemzőit kultúrtörténeti, demográfiai, neveléstörténeti és filozófiai szempontból egyaránt, amely egy történeti alapon nyugvó munkának erőssége. Ezekről, és a vizsgált időszak kiválasztásának motívumáról részletesen olvashatunk a mű harmadik és negyedik fejezetében. Az ötödik fejezet részletesen bemutatja a kutatási módszereket, a hato-

* Az Eötvös Loránd Tudományegyetem Tanító- és Óvóképző Karának adjunktusa. E-mail: pirka.veronika@ppk.elte.hu 
dik pedig a korszak jellegzetes gyermekkorhoz kapcsolódó problémaköreit részletezi képelemzésekkel és sorozatelemzésekkel. A feldolgozás során gyermekkép narratívákat mutat be a reneszánsz korából festmények, miniatúrák és ősnyomtatványok alapján, hiszen ezek is az elsődleges forrásai az adott történeti korszak gyermekreprezentációinak.

A mű elsődleges célja a "reneszánsz gyermekképének árnyalása” (Endrődy-Nagy, 2015. 5.), ahogy maga Endrődy-Nagy Orsolya fogalmaz. A következő, gyermekkort érintő problémakörök jelennek meg a munkában, mint a születés, a csecsemők élete, a betegség és a halál, illetve a játék kategóriájában. Részletesen olvashatunk a fogantatásról és terhességről, szülésről, császármetszésről, szoptatásról, pólyázásról és tisztaságról. Ismerték a korszakban a magzat különféle elhelyezkedési lehetőségeit édesanyja hasában, a várandósság állomásait. Ugyanakkor a szüléskor az újszülöttet megmosták, de az édesanyát nem, aminek következményeként meg is halhatott. A gyermeki élet értékét mutatja be az anyai élet értékével szemben. A szerző szerint viszont a tisztaság inkább lelki értelemben lehetett fontos az adott időszakban az eredendő bűntől való megtisztulás magyarázatával. Endrődy-Nagy különböző „orvosi műszereket” is bemutat, amelyeket a szülés során használtak.

A szerző a források feldolgozása alapján megállapítja, hogy az ábrázolt gyermekek játékosak, csalafinták, izgatottak. A gyermek a világát a felnőtt világgal szorosan összefűzve éli. A szülői hozzáállás a szeretetet, óvást és védelmet hangsúlyozza. A sorozatelemzéseken keresztül mutatja be Endrődy-Nagy azt, hogyan váltotta fel a pólyát a gyermek mozgásának megfelelő ruházat. A „becsomagolásos” vagy betekeréses pólyázás a képekről az 1480-as évekre eltűnt. Az elmúláshoz kapcsolódóan a gyermekhalandóságról és a halálhoz való viszonyról megállapítja, hogy a szülők gyermekeik elmúlásához tanácstalanul álltak hozzá, a korszak mentalitásában gyökerező elképzelésekhez ragaszkodva reménykedtek, hogy Isten megmenti gyermekeiket a bajtól.

A mű erősségei közé sorolhatjuk, hogy széles látókörről árulkodó tudománytörténeti munka. A neveléstörténeti kutatásokban egyre gyakrabban alkalmazott képelemzési metódust részletesen bemutatja, mintát adva más kutatóknak is a módszer használatához. A reneszánsz kori gyermekábrázolás azon időszakát mutatja be, amelyről még keveset tudunk. Aki szereti a mikrotörténetet, az anyák, szülők és gyermekek történetét, az részletesen olvashat a fogantatástól kezdve a születésen át az elmúlásig az emberek mindennapjairól, a nevelési elvekről, gyermekképről és gyermekfelfogásról. Endrődy-Nagya könyv megjelenése óta is a témához kapcsolódó kutatásokat folytat, egy magyar és egy angol nyelvű tanulmány mutatja be az újabb eredményeket (EndrődyNagy, 2016; Endrődy-Nagy, 2017).

\section{Szakirodalom}

1. Boutaud, J.-J. (1989): Application des reserches en iconographie publicitaire á la pédagogie de l'expression en I.U.T. ANRT, Lille 3, France.

2. Collier, M. (2010): Approches to analysis in visual antropology. In: van Leeuwen, T. and Jewitt, C. (eds.): Handbook of Visual Analysis. Sage, Los Angeles - London - New Delhi - Singapore - Washington. 35-61.

3. Cunningham, H. (2005): Children and Childhood in Western Society Since 1500. Pearson Education Limited, London.

4. Endrődy-Nagy Orsolya (2013): Középkor és reneszánsz - adalékok egy lehetséges gyermekképi paradigmaváltáshoz. Gyermeknevelés, 1. 63-72.

5. Endrődy-Nagy Orsolya (2017): A gyermekkortörténeti ikonográfia kutatási irányai és lehetőségei. Gyermeknevelés, 1. 110-122.

6. Endrődy-Nagy, O. (2016): Paintings and Illuminated Manuscripts as Sources of the History of Childhood: Conceptions of Childhood in the Renaissance. In: Benedek, A. and Veszelszki, Á. (eds.): In the Beginning 
was the Image: The Omnipresence of Pictures, Time, Truth, Tradition. Peter Lang GmbH, Internationaler Verlag der Wissenschaften, Frankfurt am Main. 91-100.

7. Mietzner, U. \& Pilarczyk, U. (2005): Methods of Image Analysis in Research in Educational and Social Sciences, 109-129. In: Mietzner, U., Myers, K. and Peim, N. (eds.): Visual History, Images of Education, Peter Lang AG, Europen Academic Publishers, Bern. 109-129.

8. Pollock, L. (1983): Forgotten Children: Parent-child relations from 1500 to 1900. Cambridge University Press, Cambridge.

9. Shahar, S. (2000): Gyermekek a középkorban. Osiris, Budapest. 